RESEARCH ARTICLE

\title{
Soil assessment for urban agriculture: a Vancouver case study
}

\author{
G.A. Oka, L. Thomas, and L.M. Lavkulich* \\ Land and Food Systems, University of British Columbia, Vancouver, B.C. Canada. V6T 1Z4. "Corresponding author: Iml@, \\ mailubc.ca
}

\begin{abstract}
With the expansion of urban agriculture in many North American cities, there is a current need to evaluate the soil and urban environment to assess potential risks of metal contamination in urban grown food. In this study, a university farm, a community garden, and a brownfield located in Vancouver, BC were characterized with respect to soil metal concentrations, atmospheric deposition of metals, and bioaccumulation of metals in Poa pratensis. Wet and dry deposition were collected over five months. Aqua regia and $\mathrm{HCl}$ extractions were used to evaluate total and labile metal fractions of $\mathrm{Zn}, \mathrm{Pb}, \mathrm{Ni}, \mathrm{Mn}$, and $\mathrm{Cu}$. Highest soil metal concentrations, atmospheric deposition flux, and bioaccumulation in Poa were found at the community garden, followed by the brownfield site, and the University of British Columbia Farm. Concentrations of Ni and Mn seem to be associated with soil parent material, while $\mathrm{Zn}, \mathrm{Pb}$, and $\mathrm{Cu}$ were indicators of industrial activity. Concentrations of metals in atmospheric deposition were not an immediate concern but their potential accumulation in the soil requires attention. The framework developed by the case study identified three factors meaningful for assessing metal contamination on an urban agriculture site: site history, atmospheric deposition trends, and parent material.
\end{abstract}

Keywords: Trace metals, urban agriculture, metal deposition

\section{Introduction}

\section{1. The challenges of urban agriculture}

Urban agriculture currently raises public health and food safety concerns because of environmental pollution in cities. In Vancouver, as in other North American cities, industries are leaving the city core resulting in vacant lots potentially contaminated with metals and other chemical products. These sites are termed "brownfields" because they qualify as "abandoned, vacant, derelict or underutilized commercial and industrial properties where past actions have resulted in actual or perceived contamination and [there remains] an active potential for redevelopment"
(BC Ministry of Environment, 2013a). These sites are often converted to community gardens or urban farms for limited tenure and are managed by individual urban growers or non-profit organizations that may not be equipped to deal with on-site contamination.

Sites of urban agriculture are commonly located in areas of high traffic density, industrial activity, and air pollution. Lee et al. (2007) and Li et al. (2001) reported atmospheric deposition as a major contributor to metal contamination in urban soils. Lead has been the most prevalent heavy metal pollutant, as it was a significant component of petroleum products 
in Canada until 1990 (Environment Canada, 2010). Historical resource-based land uses in the Fraser Valley of B.C. also led to recorded high emissions of $\mathrm{Pb}, \mathrm{Ni}$, and $\mathrm{Zn}$ during 1960-1966 (Pott and Turpin, 1996). Since plant uptake and groundwater leaching tend to be low, metals persist in soils for long periods of time causing unique environmental concerns (Dudka et al., 1996). The variability of emission rates, metal bioavailability in soils, and plant uptake increases the complexity of addressing atmospheric deposition and limits comparability among studies. Few studies have investigated metals in the urban environment from the perspective of how long-term atmospheric deposition and contamination of soils can impact metal bioaccumulation in vegetation.

\subsection{Sources and pathways of metal contamination in urban soils}

Since metals of anthropogenic origin have been found to be more mobile and bioavailable than metals of lithogenic and pedogenic origin (Kabata-Pendias, 2001), accumulation of metals in urban dust and soils may be of particular concern. Metals may include $\mathrm{Cd}, \mathrm{Cu}, \mathrm{Mn}, \mathrm{Ni}, \mathrm{Zn}, \mathrm{As}$, and $\mathrm{Pb}$ originating from soil amendments such as commercial fertilizers, liming materials, agrochemicals, sewage sludge and irrigation water (He et al., 2005). Past land uses such as recycling and disposal of metallurgical, municipal and industrial waste on-site can also result in the creation of waste dumps which promote the corrosion of metals and leaching of mobile constituents into the underlying soil (Alloway, 1995). Contamination of urban soils, most substantially from $\mathrm{Zn}, \mathrm{Pb}$, and $\mathrm{Cu}$, have been found in industrialized cities across the world: Hong Kong (Li and Liu, 2001), New Delhi (Singh and Kumar, 2006), and Toronto (Wiseman et al., 2013). Thus, it is likely that metal concentrations at brownfield sites in Vancouver will be enriched in comparison to background levels.

The geochemistry of soils reflects the influences of both natural soil formation processes and human additions on the existing parent material. Parent materials rich in clay tend to have relatively high natural metal concentrations due to their high adsorption capacity (Alloway 1995). The parent material of the podzolic soils, in the Vancouver area, originated from coarse textured glacial, marine, or glacial-marine till and contain appreciable amounts of $\mathrm{Al}, \mathrm{Fe}$, and $\mathrm{Mn}$ (Iverson, 2012). These oxides and hydroxides form strong bonds with metals that may function to limit the mobility of metal contaminants. Soil age may also play a role; in fresh soils that have not been exposed to leaching or with limited organic matter amendments, metals may be more bioavailable to plants because they are not tightly held in the mineral matrix or in stable humic compounds (Wiseman et al., 2013).

Humans can be exposed to metals in soils through direct dermal contact with and/or ingestion of contaminated soils, as well as through inhalation of contaminated soil in the form of dust (Dudka et. al., 1996). Humans may also consume metals in the form of contaminated crop plants. Contamination of surface layers occurs as a result of atmospheric contributions of metal-containing exhaust deposits, often onto the leaf surface; while intrinsic contamination occurs through uptake of soil contaminants and storage in edible plant parts. Translocation and bio-accumulation of metals from soil to aboveground plant parts is variable by plant species and genotype (Peijenburg et al., 2006). Singh and Kumar (2006) found $\mathrm{Pb}$ and $\mathrm{Cd}$ to be mainly taken up through foliar deposition, while $\mathrm{Cu}$ and $\mathrm{Zn}$ through uptake from the soil. As such, leafy vegetation were found to predominantly accumulate metals from atmospheric deposition,while fruit or root-based vegetation accumulate metals from the soil.

\subsection{Atmospheric deposition trends}

Metal emissions may be moderated by seasonal trends; Lee et al. (2007) found the atmospheric load of Cd, $\mathrm{Pb}, \mathrm{V}$, and $\mathrm{Zn}$ to be highest during the winter and lowest during the summer. On a regional scale, Pott and Turpin (1998) noted a decline of metal deposition along a west-east gradient in Metro Vancouver, reflecting higher population densities along the coast. 
Contrasting south-east/north-west winds and a thermal sea breeze pattern circulates atmospheric metals within this region. However, limited studied have been done on the magnitude of metal deposition in Metro Vancouver. Gelinas and Schmit (1998) observed that enrichment of metals from major roads decreased with distance and approached background levels at $\sim 100 \mathrm{~m}$ from a major road. Alternatively, Toronto Public Health (2011) has suggested that a $30 \mathrm{~m}$ threshold distance is sufficient for reducing metal contamination concern.

\subsection{Study Objectives}

The purpose of this study is to provide an initial assessment of metal contamination of established and potential food-growing sites in Vancouver's urban soils. The assessment addresses the metal contents and accumulation in atmospheric deposition, soil, and subsequent bio-concentration in vegetation. Three sites were selected which exhibit a range of exposure to industrial activity, and soil metal contamination.

\section{Methodology}

\subsection{Site history and sampling}

Trace metal concentrations were assessed at three urban sites in Vancouver. Site history was investigated prior to sampling via information from the City of Vancouver and firsthand accounts from community members in each neighbourhood. Site assessment included an evaluation of topography, soil compaction, evidence of possible contamination (i.e. odours, oil slicks, anthropogenic debris), and type/presence of vegetation. Soil samples were taken from the top 0-30 cm of soil (the depth of rooting of most annual plants). Particular areas of interest included areas slated to be garden beds or play areas, and areas where contamination was suspected. Study sites included the UBC Farm at the University of British Columbia, the 16 Oaks community garden in the Shaughnessy neighbourhood, and a brownfield site on Hastings Street and Glen Drive in the Strathcona neighbourhood (Figure 1).

The UBC Farm is a 24 ha university research site which integrates cultivated field areas with hedgerows, orchards, and maturing successional forest stands (UBC Farm, 2009). It is located in the sparsely populated South Campus of UBC which has experienced large scale development of residence buildings and shopping malls only within the last decade. The soil originates from glacial till parent material and is well-drained and sandy. It has been managed for the past 40 years with incorporation of organic matter into the topsoil (UBC Farm, 2009).

The 16 Oaks community garden was established in 2008; prior to that, the site was vacant for approximately ten years following the removal of a restaurant and parking lot. Oak Street and $16^{\text {th }}$ Avenue is a moderately high traffic intersection; it serves as a major bus route and borders a predominantly residential area. The site is level and measures $1340 \mathrm{~m}^{2}$ in area with soils originating from glacial marine parent material. No edible vegetation is grown in the native soil; various species of flowers and vegetables are grown on raised bed plots.

The Hastings site, $2130 \mathrm{~m}^{2}$ in area, has been vacant for the past forty years (City of Vancouver, personal communication, January 15, 2012). It has a northern aspect and a relief of 2-3 metres from east to west. The Hastings brownfield is located on the northeast corner of the Georgia Street viaduct. The viaduct serves as a high traffic roadway and the Strathcona neighbourhood is populated by various industries. From 1955 to 1970, the site was used as a scrap metal yard. Attempts to remediate the soil included the addition of various layers of construction fill including medium sand and gravel for topsoil which overlays a metal-containing sand fill. The native soil, originating from marine parent material is deposited 1-2.5 metres below the surface. Site observations revealed that the soil is spatially heterogeneous and compacted in areas, with remnants of metal parts present within $30 \mathrm{~cm}$ of the soil surface. The whole site is occupied by grasses, and regionally invasive shrubs and vines. 


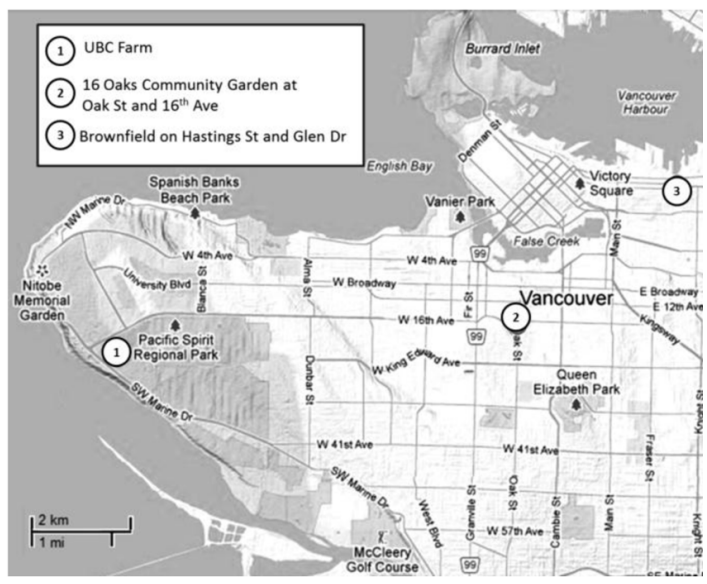

Figure 1. Locations of the study sites in Vancouver, British Columbia.

\subsection{Testing for metals in soil, Kentucky bluegrass, and atmospheric deposition}

Laboratory analysis included $\mathrm{pH}$, organic matter content, and total and labile fraction extraction of metal contaminants of interest. In addition to soil sampling, native vegetation and atmospheric deposition were collected to determine an empirical relationship between traffic density and metal deposition. A stratified-random sampling design was applied to this study since limited information was available about the metal distribution at these sites. Two sampling events took place over October 2011 to February 2012 for the collection of individual and composite topsoil $(0-20 \mathrm{~cm})$ samples, and root and shoot samples of Kentucky bluegrass (Poa pratensis), a hardy lawn grass common to all three sites. Wet and dry deposition was collected using an atmospheric deposition filter and rainwater collector that was placed at each of the sites near the location of soil and vegetation sampling. The system included a funnel which contained a $2.5 \mu \mathrm{m}$ filter (Whatman 42) housed in a wire chamber; the funnel was attached to a hose and a four-litre collection bottle. For the purposes of this study, "soluble" elements were categorized as those being less than $2.5 \mu \mathrm{m}$ in diameter. Collection of dry and wet deposition was carried out during the wet season, starting from October and continuing for five months until March 2012.

Soil samples were air-dried for 48 hours prior to analysis. Vegetation samples (leaves and roots) were thoroughly rinsed with deionized water and dried, prior to being analyzed. Soils were sieved through a $2 \mathrm{~mm}$ stainless steel sieve and soil $\mathrm{pH}$ was measured at 1:2 or 1:5 ratio in water and $1: 3$ in a $0.01 \mathrm{M} \mathrm{CaCl}_{2}$ solution (Hendershot et al., 1993). An estimate of organic matter was determined for soil samples initially dried at $105^{\circ} \mathrm{C}$ and vegetation samples at $70^{\circ} \mathrm{C}$ prior to measurement by loss on ignition at $350^{\circ} \mathrm{C}$ and $550^{\circ} \mathrm{C}$ (Atkinson et al.,1958). Five metals were selected for consideration, $\mathrm{Zn}, \mathrm{Pb}, \mathrm{Ni}, \mathrm{Mn}$, and $\mathrm{Cu}$, as indicators of contamination. Two types of extractions were completed for comparative purposes to assess total and labile soil metal concentrations. Aqua regia extraction was applied to all soil and vegetation samples as described by Cheng and $\mathrm{Ma}$ (2001). $\mathrm{HCl}$ (at $0.1 \mathrm{M}$ dilution) was used to extract soil, and wet and dry deposition. This extraction method (Snape et al., 2004) approximates the labile or mobile phases of metals (eg. water soluble and exchangeable fractions) in the soil or sediment as the proportion of metals available for plant uptake. All samples were analyzed using an inductively coupled plasma atomic emission spectrometer (ICP-AES). 


\section{Results}

Data from the two sampling events were combined as no obvious differences in metal concentrations were observed. Soil properties of the farm, garden and brownfield are given in Table 1. $\mathrm{pH}$ at the farm and brownfield were slightly acidic, while $\mathrm{pH}$ at the garden was closer to neutral. Loss on ignition estimates of organic matter were highest at the farm where values were doubled that of the other two sites.

Table 1. Mean values for $\mathrm{pH}$ and loss on ignition for topsoil at the three study sites.

\begin{tabular}{|c|c|c|c|c|c|}
\hline Site & $\begin{array}{c}\text { Sample Type } \\
(0-20 \mathrm{~cm})\end{array}$ & $\begin{array}{l}\text { Sample } \\
\text { Size }\end{array}$ & $\begin{array}{l}\mathrm{pH} \text { in } \\
\text { Water }\end{array}$ & $\begin{array}{l}\mathrm{pH} \text { in } \\
0.01 \mathrm{M} \\
\mathrm{CaCl}_{2}\end{array}$ & $\begin{array}{c}\text { LOI at } \\
350^{\circ} \mathrm{C}(\%)\end{array}$ \\
\hline UBC Farm & Native soil & 9 & 5.80 & 5.16 & 11.7 \\
\hline $\begin{array}{c}16 \text { Oaks Community } \\
\text { Garden }\end{array}$ & Surface material & 9 & 6.20 & 5.90 & 6.92 \\
\hline Hastings Brownfield & Surface material & 14 & 5.84 & 5.14 & 4.95 \\
\hline
\end{tabular}

Total metal concentrations were highest at the 16 Oaks community garden and lowest at the UBC Farm (Figure 2), which may be reflective of the more rural location of the farm, in contrast to the high traffic volume of the urban setting at the $16^{\text {th }}$ Avenue and Oak Street intersection. The disparity in urban-rural soil metal concentrations have been observed by Li et al. (2001) and Salonen and Korkka-Niemi (2007).

Metal contributions via atmospheric deposition were also lowest at the farm and higer at the Hastings site, where the influence of shipping traffic at the ocean inlet may impact the metal concentrations meaningfully. Table 2 provides data on the variability of metal contents both within and among the sampled sites. A result of the various disturbances characteristic of urban sites is the greater variation in metal contents at 16 Oaks and the Hastings brownfield, as expressed by the range of values around the mean. Across all sites the order of available metal concentrations was $\mathrm{Mn}>\mathrm{Zn}>\mathrm{Pb}>\mathrm{Cu}>\mathrm{Ni}$. $\mathrm{Zn}$ concentrations were very low at the UBC Farm and 4-5 times higher at 16
Oaks and the Hastings brownfield; $\mathrm{Pb}$ was highest at 16 Oaks and lowest at the UBC Farm; Ni and Mn concentrations were similar among all sites; and $\mathrm{Cu}$ was only sizable at the Hastings brownfield. Site history may be especially relevant to account for the enrichment of $\mathrm{Zn}, \mathrm{Pb}$, and $\mathrm{Cu}$ at the Hastings brownfield, which was previously a dumpingground for metallurgical materials. The relatively high Mn concentration at the UBC Farm can be attributed in part to naturally high concentrations of metals found in parent material rich in clays (Salonen and Korkka-Niemi, 2007).

Topsoil (native soil or surface material) metal concentrations extracted by Aqua regia and $0.1 \mathrm{M}$ $\mathrm{HCl}$ were similar in their relative proportions. The ratio between total and labile metal concentrations ranged from 2 to 4 for $\mathrm{Zn}$; approximately 3 for $\mathrm{Pb}$ to as high as 15 (for the UBC Farm); 5 to 8 for Ni; approximately 2 for $\mathrm{Mn}$; with greatest variability for $\mathrm{Cu}$, ranging from 2-12. This suggests that with the possible exception of $\mathrm{Cu}, \mathrm{HCl}$ extraction, a much simpler laboratory protocol than Aqua regia, may be used as a proxy for an initial assessment 
of potentially contaminated soil. Table 3 presents the mean and range of concentrations for metals in grass samples collected at the study sites. With few exceptions, a greater concentration of metals was found in the shoots than roots of Kentucky bluegrass, consistent with findings by Padmavathiamma and $\mathrm{Li}$ (2009). $\mathrm{Zn}$ and $\mathrm{Pb}$ concentrations are high at 16 Oaks and the Hasting brownfield and considerably lower at the UBC Farm, while $\mathrm{Cu}$ concentrations were only elevated at the Hastings brownfield. In contrast, Ni and Mn concentrations are similar across all sites. Greater variability overall is observed in the grass samples, notably for the UBC Farm where the highest mean concentration for Mn was found, perhaps as a result of the parent material of soil Mn (Luttmerding, 1981). The order of abundance for metals is similar to available metals in the soil with either $\mathrm{Zn}$ or $\mathrm{Mn}$ being most abundant. The ratio of metals in the roots and shoot ranged from 0.3 to 1 for $\mathrm{Zn} ; 0.7$ to 1 for $\mathrm{Pb}$; 0.4 to 0.7 for $\mathrm{Ni}$ and approximately 0.4 to 1.2 for $\mathrm{Mn}$ and $\mathrm{Cu}$. Results are consistent with Padmavathiamma and $\mathrm{Li}$ (2009) for $\mathrm{Zn}, \mathrm{Pb}$, $\mathrm{Mn}$, and $\mathrm{Cu}$. These results suggest that concerns regarding toxic effects of consuming plants on such sites extend beyond metal concentrations in soil and plant roots as the effect of bioaccumulation and translocation to edible plant parts may be substantial. Clearly, advocating for an expansion of urban agriculture warrants additional work for individual plant species as well as site conditions.

Although the data is limited and preliminary, atmospheric metal inputs into the study sites were predominantly in the form of dry deposition, affirming findings by Harrison and Chirgawi (1989). Differences in metal concentrations of up to five orders of magnitude were found. Metal concentrations in wet deposition were consistent with the range observed in snowpack in eastern Canada by Barrie and Vet (1984). Evaporated deposition samples were not weighed, thus flux calculations in Table 4 approximate contributions from dry deposition only. The relative order of abundance of metals is $\mathrm{Zn}>\mathrm{Cu} \approx \mathrm{Pb}>\mathrm{Ni}>\mathrm{Mn}$ Dry deposition fluxes ranged from nearly $1600 \mu \mathrm{g} /$ $\mathrm{m}^{2} /$ day for $\mathrm{Zn}$ to less than $2 \mu \mathrm{g} / \mathrm{m}^{2} /$ day for $\mathrm{Mn}$. Metal concentrations for $\mathrm{Mn}$ and $\mathrm{Pb}$ are within the low range observed by Brewer and Belzer (2001) at Burnaby Lake. The 16 Oaks Community Garden exhibited the highest flux for all metals followed by the Hastings Brownfield and the UBC Farm. The difference in flux between each site is approximately three-fold for $\mathrm{Zn}$, and two-fold for $\mathrm{Pb}$ and $\mathrm{Cu}$ between the UBC Farm and the Hastings Brownfield.

These findings are consistent with deposition patterns of metals in urban and rural settings in eastern Canada where $\mathrm{Zn}$ and $\mathrm{Cu}$, metals commonly associated with transportation sources, were found to accumulate in industrial areas (Barrie and Vet, 1984). Since $Z n$ is commonly emitted from vehicular traffic and tire wear, the notably high $\mathrm{Zn}$ flux at 16 Oaks may be largely attributed to road dust and the high traffic density observed at this site. The large flux of $\mathrm{Pb}$ and $\mathrm{Cu}$ at the 16 Oaks and Hastings site suggests that a local source is contributing to these metal concentrations; this may be attributed to the proximity of the 16 Oaks site to shipping routes for the Canadian National Railway and the Burlington Northern-Santa Fe Railway, and the proximity of the Hastings site to the Vancouver Wharves Terminal (i.e. aviation float planes and helicopters) and to the shipping route for the British Columbia Railway (Port Metro Vancouver, 2010). Although $\mathrm{Pb}$ is no longer used as a gasoline additive, higher concentrations appear to be associated with high traffic areas consistent with Brewer and Belzer's (2001) findings for the persistence of residual $\mathrm{Pb}$ in particulate metal concentrations measured at Burnaby Lake.

The results demonstrate the need to address atmospheric contributions as well as soil metal concentrations in making a true assessment of metal contents in urban soils and plants that are grown for human consumption. 


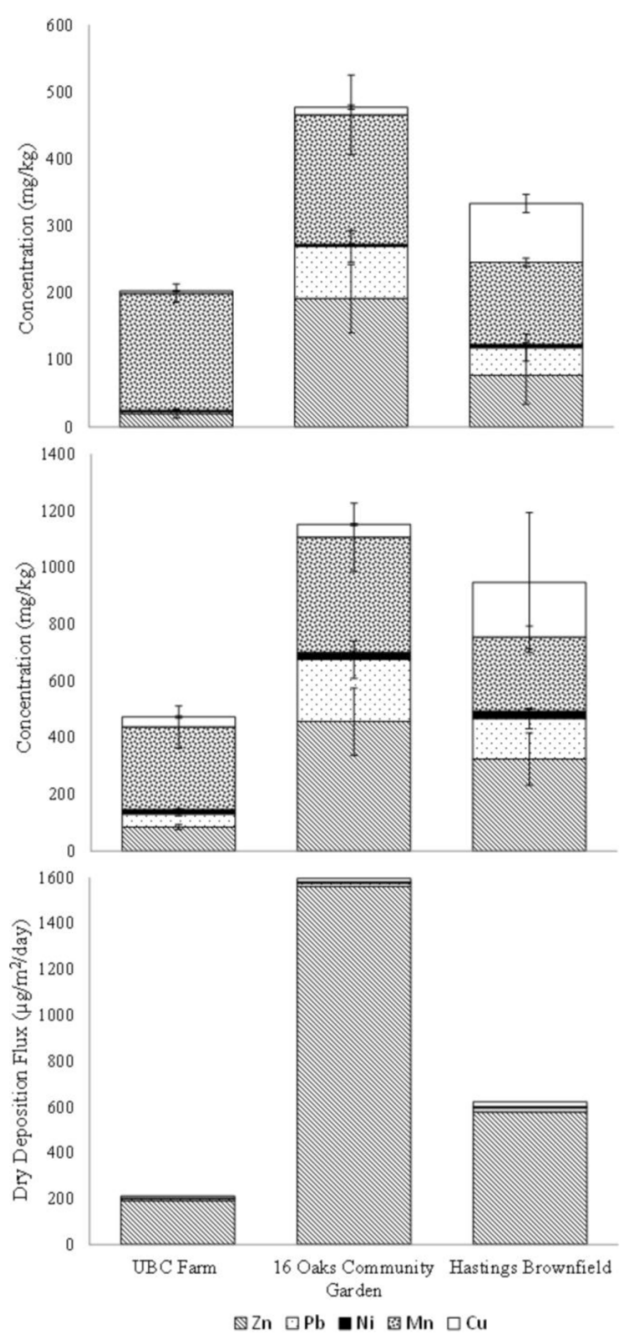

Figure 2. a) Total (Aqua regia extraction) soil metal concentrations; b) labile (0.1 $\mathrm{M} \mathrm{HCl}$ extraction) soil metal concentrations; and c) dry deposition metal flux at the three study sites. Standard error bars are shown. 
Table 2. Maximum, mean, and minimum concentrations of $\mathrm{Zn}, \mathrm{Pb}, \mathrm{Ni}, \mathrm{Mn}$ and $\mathrm{Cu}$ in topsoil at the three study sites, extracted using Aqua regia and $0.1 \mathrm{M} \mathrm{HCl}$.

\begin{tabular}{|c|c|c|c|c|c|c|c|c|}
\hline Site & $\begin{array}{l}\text { Extraction type } \\
\text { for topsoil } \\
(0-20 \mathrm{~cm})\end{array}$ & $\begin{array}{c}\text { Sample } \\
\text { Size }\end{array}$ & & $\mathbf{Z n}$ & $\mathrm{Pb}$ & $\begin{array}{c}\mathrm{Ni} \\
(\mathrm{mg} / \mathrm{kg})\end{array}$ & Mn & $\mathrm{Cu}$ \\
\hline \multirow{6}{*}{ UBC Farm } & \multirow{4}{*}{ Aqua regia } & \multirow{6}{*}{9} & $\operatorname{Max}$ & 133 & 81.8 & 37.4 & 785 & 55.2 \\
\hline & & & Mean & 85.1 & 44.9 & 16.4 & 291 & 35.4 \\
\hline & & & Min & 50.7 & 21.8 & 6.1 & 110 & 23 \\
\hline & & & $\operatorname{Max}$ & 72.2 & 5.5 & 4.5 & 234 & 7.7 \\
\hline & \multirow[t]{2}{*}{$0.1 \mathrm{M} \mathrm{HCl}$} & & Mean & 20.1 & 3 & 1.8 & 175 & 3.2 \\
\hline & & & Min & 7.7 & 1.4 & 0.7 & 97.7 & 1.6 \\
\hline \multirow{6}{*}{$\begin{array}{l}16 \text { Oaks } \\
\text { Community } \\
\text { Garden }\end{array}$} & \multirow{3}{*}{ Aqua regia } & \multirow{6}{*}{9} & Max & 1320 & 234 & 56.7 & 1230 & 62.8 \\
\hline & & & Mean & 456 & 219 & 24.3 & 407 & 45 \\
\hline & & & Min & 160 & 110 & 13.7 & 113 & 35.7 \\
\hline & \multirow{3}{*}{$0.1 \mathrm{M} \mathrm{HCl}$} & & $\operatorname{Max}$ & 456 & 240 & 5.1 & 547 & 35.6 \\
\hline & & & Mean & 191 & 78.1 & 2.9 & 193 & 11.2 \\
\hline & & & Min & 60 & 15 & 1.4 & 69.1 & 2.2 \\
\hline \multirow{6}{*}{$\begin{array}{l}\text { Hastings } \\
\text { Brownfield }\end{array}$} & \multirow{3}{*}{ Aqua regia } & \multirow{6}{*}{14} & $\operatorname{Max}$ & 1080 & 499 & 90 & 593 & 3610 \\
\hline & & & Mean & 324 & 143 & 26.1 & 260 & 193 \\
\hline & & & Min & 63 & 46 & 9.2 & 122 & 45.8 \\
\hline & \multirow{3}{*}{$0.1 \mathrm{M} \mathrm{HCl}$} & & $\operatorname{Max}$ & 561 & 224 & 38.2 & 179 & 193 \\
\hline & & & Mean & 76.8 & 41.6 & 4.7 & 122 & 87.9 \\
\hline & & & Min & 15.9 & 11.8 & 2.8 & 99.5 & 17.7 \\
\hline
\end{tabular}

Table 3. Maximum, mean, and minimum concentrations of $\mathrm{Zn}, \mathrm{Pb}, \mathrm{Ni}, \mathrm{Mn}$ and $\mathrm{Cu}$ in root and shoot of Poa pratensis at the three study sites.

\begin{tabular}{|c|c|c|c|c|c|c|c|c|}
\hline Site & $\begin{array}{c}\text { Kentucky } \\
\text { Bluegrass } \\
\text { (Poa pratensis) }\end{array}$ & $\begin{array}{c}\text { Sample } \\
\text { Size }\end{array}$ & & $\mathrm{Zn}$ & $\begin{array}{l}\mathrm{Pb} \\
(\mathrm{mg} /\end{array}$ & $\begin{array}{c}\mathrm{Ni} \\
\mathrm{g} \text { dry m }\end{array}$ & $\begin{array}{l}\text { Mn } \\
\text { atter) }\end{array}$ & $\mathrm{Cu}$ \\
\hline \multirow{6}{*}{ UBC Farm } & \multirow{3}{*}{ Root } & \multirow{3}{*}{5} & $\operatorname{Max}$ & 221 & 71.9 & 33.4 & 541 & 92 \\
\hline & & & Mean & 174 & 53 & 15 & 427 & 72.4 \\
\hline & & & Min & 87.4 & 43.4 & 2.7 & 262 & 48 \\
\hline & \multirow{3}{*}{ Shoot } & \multirow{3}{*}{6} & $\operatorname{Max}$ & 2260 & 105 & 97.7 & 2920 & 264 \\
\hline & & & Mean & 738 & 82.2 & 36 & 1350 & 150 \\
\hline & & & Min & 285 & 62 & 7.2 & 748 & 81.2 \\
\hline \multirow{6}{*}{$\begin{array}{l}16 \text { Oaks } \\
\text { Community } \\
\text { Garden }\end{array}$} & \multirow{3}{*}{ Root } & \multirow{3}{*}{5} & $\operatorname{Max}$ & 2970 & 1130 & 62.5 & 790 & 161 \\
\hline & & & Mean & 1360 & 455 & 35.8 & 399 & 106 \\
\hline & & & Min & 607 & 157 & 12.4 & 165 & 63.5 \\
\hline & \multirow{3}{*}{ Shoot } & \multirow{3}{*}{6} & $\operatorname{Max}$ & 2990 & 923 & 121 & 1070 & 230 \\
\hline & & & Mean & 1330 & 387 & 53.3 & 506 & 148 \\
\hline & & & Min & 430 & 178 & 7.2 & 88.5 & 85.3 \\
\hline \multirow{6}{*}{$\begin{array}{l}\text { Hastings } \\
\text { Brownfield }\end{array}$} & \multirow{3}{*}{ Root } & \multirow{3}{*}{5} & $\operatorname{Max}$ & 1070 & 198 & 63.8 & 594 & 583 \\
\hline & & & Mean & 843 & 172 & 46 & 403 & 448 \\
\hline & & & Min & 491 & 102 & 34.4 & 201 & 259 \\
\hline & \multirow{3}{*}{ Shoot } & \multirow{3}{*}{6} & Max & 1930 & 702 & 145 & 1860 & 616 \\
\hline & & & Mean & 905 & 253 & 63.7 & 814 & 290 \\
\hline & & & Min & 326 & 83.3 & 22.7 & 172 & 104 \\
\hline
\end{tabular}


Table 4. Mean dry deposition flux of $\mathrm{Zn}, \mathrm{Pb}, \mathrm{Ni}, \mathrm{Mn}$, and $\mathrm{Cu}$ at the three study sites.

\begin{tabular}{cccccc}
\hline Site & Zn & Pb & $\begin{array}{c}\text { Ni } \\
\text { Flux }\left(\mu \mathrm{g} / \mathbf{m}^{2} / \text { day }\right)\end{array}$ & Mn & Cu \\
\hline UBC Farm & 191 & 7.40 & 2.28 & 1.61 & 8.31 \\
\hline $\begin{array}{c}\text { 16 Oaks Community } \\
\text { Garden }\end{array}$ & 1560 & 14.2 & 2.39 & 4.07 & 14.9 \\
\hline Hastings Brownfield & 578 & 16.7 & 3.48 & 2.58 & 21.5 \\
\hline
\end{tabular}

\section{Discussion}

\subsection{Soil factors impacting metal accumulation and availability}

The similar concentrations of $\mathrm{Ni}$ and Mn metals across the topsoil and subsoil within each site suggests that for immature soils the influence of the original parent material is larger than the atmospheric load (Salonen and Korkka-Niemi, 2007). The divergence in values for $\mathrm{Zn}, \mathrm{Pb}$ and $\mathrm{Cu}$ may be attributed to specific site history and local deposition trends at the 16 Oaks and Hastings sites. Total metal concentrations in soils and parent materials in the Lower Fraser Valley range from 50 to $150 \mathrm{ppm}$ for $\mathrm{Zn}, 20$ to over $920 \mathrm{ppm}$ for $\mathrm{Mn}$, and 20 to $50 \mathrm{ppm}$ for $\mathrm{Cu}$ (Luttmerding, 1981). Background soil metal concentrations found for $\mathrm{Pb}$ and $\mathrm{Ni}$ are $60 \mathrm{ppm}$ and $80 \mathrm{ppm}$, respectively (B.C. Ministry of Environment, 2013b). Based on these estimates metal concentrations at the UBC Farm can be considered near background levels, while 16 Oaks and the Hastings brownfield exhibit elevated levels for $\mathrm{Zn}$ and $\mathrm{Pb}$ and $\mathrm{Zn}, \mathrm{Pb}$ and $\mathrm{Cu}$, respectively. The elevated metal concentrations in sites with greater industrial activity are consistent with anthropogenic inputs of metals.

Since $\mathrm{pH}$ is one of the main factors determining metal mobility, the close agreement of slightly acidic $\mathrm{pH}$ values $(>5.5)$ at all three sites indicates that current soil conditions may be limiting the bioavailability of trace metals to plants. $\mathrm{Cu}$ is specifically adsorbed in soils decreasing its potential as a mobile trace metal, while $\mathrm{Pb}$ is reported to be the least mobile trace metal (Kabata-Pendias, 2001).

Translocation of metals from roots to shoots depends on both the metal and the variety of plant. Plant uptake of metal contaminants is influenced by the morphology of the leaves as determined by conditions of plant growth (Peijenburg et al., 2006). Through regression analysis, Padmavathiamma and Li (2009) found that root length, shoot length and the number of branches/root are the main factors influencing metal concentrations in plants. Heterogeneous growth conditions were observed within and among the sites, thus the degree of foliar uptake could not be accounted for in this study. Padmavathiamma and Li (2009) found Poa to have phytostabilization capacity (i.e. higher accumulation in the roots as compared to shoots) in highways soils for $\mathrm{Zn}, \mathrm{Pb}, \mathrm{Mn}$, and $\mathrm{Cu}$ with highest accumulation for Mn. In this study, higher concentrations tended to occur in shoots with inconsistency among sites, which may be attributed to the method of passive metal uptake observed for this plant (Peijenburg et al., 2006). The degree of plant metal bio-accumulation was found to reflect soil metal concentrations suggesting that Poa has limited preference for accumulation in specific vegetative parts. As a consequence of the limited sampling size, it is inconclusive if meaningful differences in uptake exist among metals. Despite the relative immobility of $\mathrm{Pb}$, it was observed to bioaccumulate in similar proportions to $\mathrm{Zn}$, which tends to efficiently translocate to all plant parts (Davies, 1995). 
Koeppe (1977) proposes that uptake of $\mathrm{Pb}$ is highly dependent on physiological status. Under conditions of optimal growth $\mathrm{Pb}$ precipitates on the root cell wall and does not accumulate in the shoots. There is also a seasonal component by which $\mathrm{Pb}$ content in grass shoots increases during autumn and winter when plants are not in their period of active growth (Mitchell and Reith, 1966). This study examined Poa during what may be its senescent stages.

\subsection{Measured deposition trends}

Calculated enrichment factors for total deposition at various non-urban and urban locations in Europe and North America is sequenced as $\mathrm{Pb}>\mathrm{Zn}=\mathrm{Cu}>\mathrm{Ni}$ $>$ Mn (Kabata-Pendias, 2001) A higher enrichment factor indicates greater importance of deposition as a source of these metals in soils and plants. This ordering generally approximates what was observed in bulk deposition in this study, with the exception of $\mathrm{Pb}$ concentrations being much lower than $\mathrm{Zn}$ concentrations. This may be attributed to the declining use of $\mathrm{Pb}$ in gasoline products post 1975 as vehicle emissions were the largest atmospheric contribution of $\mathrm{Pb}$. Metals in street dust have been found to have higher concentrations and mobility than metals in urban soils because of their adsorption to coarsesized, easily weathered calcite minerals (Li et al., 2001). While $\mathrm{Zn}, \mathrm{Pb}$ and $\mathrm{Cu}$ seem to be associated to anthropogenic activities $\mathrm{Ni}$ and $\mathrm{Mn}$ may be within background concentrations across all sites. This study has not been able to evaluate micro-climate effects on deposition of metals or the range of impact of emissions sources. From observation, the high flux of metals in dry deposition largely correspond to resuspended soil particles, road dust, and industrial combustion products that due to their relatively large size tend to deposit close to the emission source. The low concentrations observed in wet deposition (particulate fraction $<2.5 \mu \mathrm{m}$ in diameter) suggest that high temperature emissions typically responsible for the emission of the fine fraction, do not contribute significantly to metal loading in these areas.
The different order of abundance of metals in soil and deposition indicates that atmospheric contributions is most meaningful for $\mathrm{Zn}$ and $\mathrm{Pb}$ which are already abundant in the soils at 16 Oaks and the Hastings brownfield. Enrichment of these metals in the soil may have occurred through long term deposition in addition to specific soil conditions. While $\mathrm{Mn}$ is relatively abundant in soils, atmospheric contribution of this metal is relatively small. This is unexpected as several Canadian studies (Simonetti et al., 2010) have found high Mn contributions and attribute it to the use of MMT as an anti-knock replacement for tetra-ethyl lead. $\mathrm{Cu}$ enrichment may be of concern only at the Hastings brownfield.

\subsection{Interpreting results within the context of provincial standards for metal contamination}

The B.C. Ministry of Environment's (2013b) total metal standards for agricultural land use according to the Contaminated Sites Regulation is $150 \mathrm{ppm}$ for Ni using a generic numerical soil standard; $450 \mathrm{ppm}$ for $\mathrm{Zn}, 1000 \mathrm{ppm}$ for $\mathrm{Pb}$, and $150 \mathrm{ppm}$ for $\mathrm{Cu}$ using a matrix numerical soil standard for toxicity to soil invertebrates and plants. No standards were provided for $\mathrm{Mn}$, suggesting that it is not a metal of concern for soil contamination. None of soils sampled from the UBC Farm contained trace metals in excess of these standards. Mean values for total $\mathrm{Zn}$ at 16 Oaks and total $\mathrm{Cu}$ at the Hastings brownfield were above these standards, but exhibited wide variability among samples. The additive load of atmospheric deposition may be significant for metals that are already abundant in these soils. It is not conclusive whether bio-concentration in shoots results from metal translocation or from absorption at the foliar surface. As such, the level of complexity involved in metal uptake and the long residence time of metals in soil should not be underestimated.

\subsection{Assessing metal contamination in urban soils}

This study revealed three factors to be relevant for urban soil metal assessment: site history, deposition 
trends, and parent material. Preliminary evaluation involved collecting site-specific information from city archives and community members, as well as observing site conditions and estimating the level of industrial activity in its proximity. Guidelines for assessing site history have been created by other Canadian cities such as Toronto (Toronto Public Health, 2011) and Montreal to determine the potential level of concern posed by a site. Secondary evaluation can be completed for sites posing medium to high levels of concern; this includes the physical testing of specific soil factors, total metal concentrations, and if feasible, deposition trends. Metal concentrations should then be evaluated according to the relevant standards under provincial or municipal regulations.

\section{Conclusion}

Three sites of interest to urban agriculture in Vancouver were investigated to determine metal accumulation from native soils/ surface material and atmospheric deposition, and the potential for subsequent bioaccumulation in $\mathrm{Poa}$ pratensis. Current industrial activity and historical metal contamination were found to impact metal accumulation of $\mathrm{Zn}, \mathrm{Pb}$, and $\mathrm{Cu}$ in soils at the 16 Oaks community garden and Hastings brownfield. Soil metal concentrations at the UBC Farm were within provincial standards for agricultural land. The proposed framework for urban soil metal assessment intends to provide a holistic strategy to address the complexity of metal accumulation in urban soils. While there remain limitations to its applicability, the outcomes of this framework can guide future management practices that minimize concerns of food safety on an urban growing site.

\section{References}

Alloway, B.J. 1995. Introduction. In: B.J. Alloway (ed). Heavy Metals in Soils, 2nd. Edition. Glasgow, pp: $3-10$.
Atkinson, H.J., Giles, G.R., MacLean, A.J., Wright, J.R. 1958. Chemical methods of soil analysis. Contribution no. 169. Chemical Division of Science Services, Ottawa.

Barrie, L.A., Vet, R.J. 1984. The concentration and deposition of acidity, major ions, and trace metals in the snowpack of the eastern Canadian Shield during the winter of 1980-1981. Atmos. Environ. 18(7), 1459-1469.

B.C. Ministry of Environment. 2013a. Brownfields and Brownfield Redevelopment. Retrieved July 5, 2014, from http://www.elp.gov.bc.ca/epd/ remediation/brownfields/index.htm.

B.C. Ministry of Environment. 2013b. Legislation and Regulations - Contaminated Sites Regulation.Retrieved October 20, 2013, from http://www.env.gov.bc.ca/epd/remediation/leg regs/csr.htm.

Cheng, M., Ma, L.Q. 2001. Comparison of three Aqua regia digestion methods for twenty Florida soils. Soil Sci. Soc. Am. 65, 491-499.

Dudka, S., Piotrowskab, M., Terelakb, H. 1996. Transfer of cadmium, lead, and zinc from industrially contaminated soil to crop plants: a field study. Environ. Pollut. 94(2), 181-188.

Environment Canada. 2010. Environment Canada's Gasoline Regulations. Retrieved on January 15, 2013, from http://www.ec.gc.ca/lcpe-cepa/ default.asp?lang $=$ En \& n $=54$ FE $5535-\% 20$ $1 \& \mathrm{wsdoc}=8 \mathrm{E} 3 \mathrm{C} 2 \mathrm{E} 9 \mathrm{~B}-38 \mathrm{~A} 8-461 \mathrm{~A}-8 \mathrm{EC} 3-$ C3AA3B1FD585\#s2.

Gelinas, Y., Schmidt, J.P. 1998. Estimation of the bulk atmospheric deposition of major and trace elements to a rural watershed. Atmos. Environ. 32, 1473-1483.

Harrison, R.M., Chirgawi, M.B. 1989. The assessment of air and soil contributors of some trace metals 
to vegetable plants I. Use of a filtered air growth cabinet. Sci. Total Environ. 83, 13-34.

He, Z.L., Yang, X.E., Stoffella, P.J. 2005. Trace elements in agroecosystems and impacts on the environment. J. Trace Elem. Med Biol. 19, 125140.

Hendershot, W.H., Lalande, H., Duquette, M. 1993. Chapter 16: Soil reaction and exchangeable acidity. In Carter, M.R. (ed.). Soil Sampling and Methods of Analysis. Lewis Publishers, Boca Raton, pp: 141-143.

Iverson, M.A., Holmes, E.P., Bomke, A.A. 2012. Development and use of rapid reconnaissance soil inventories for reclamation of urban brownfields: A Vancouver, British Columbia, case study. Can. J. Soil Sci. 92, 191-201.

Kabata-Pendias, A. 2001.Trace Elements in Soils and Plants.Third Edition.CRC Press, Boca Raton.

Koeppe, D.E. 1977. The uptake, distribution, and effect of cadmium and lead in plants. Sci. Total Environ. 7(3), 197-206.

Lee, C.S., Lia, X., Zhang, G., Li, J., Ding, A., Wang. T. 2007. Heavy metals and $\mathrm{Pb}$ isotopic composition of aerosols in urban and suburban areas of Hong Kong and Guangzhou, South China: Evidence of the long-range transport of air contaminants. Atmos. Environ. 41, 432-447.

Li, X., Poon, C., Liu, P.S. 2001. Heavy metal contamination of urban soils and street dusts in Hong Kong. Appl. Geochem. 16, 1361-1368.

Luttmerding, H.A., 1981. Soils of the LangleyVancouver Area Map: Volume 3: Description of the Soils. Kelowna, BC. BC Ministry of the Environment.ISSN 0375-5886.

Mitchell, R.L., Reith, J.W.S. 1966.The lead content of pasture herbage. J. Sci. Food. Agric. 17, 437-440.
Padmavathiamma, P.K., Li., L.Y. 2009. Phytoremediation of metal-contaminated soil in temperate humid regions of British Columbia, Canada. Int. J. Phytorem. 11, 575-590.

Peijenburg, W.J.G.M., Zablotskaja, M., Vijver, M.G. 2007. Monitoring metals in terrestrial environments within a bioavailability framework and a focus on soil extraction. Ecotox. Environ. Safe. 67, 163-179.

Port Metro Vancouver. 2010. Rail freight service review: Submission to the transport Canada rail freight service review panel. Vancouver, BC.

Pott, U., Turpin, D.H. 1996. Changes in atmospheric trace element deposition in the Fraser Valley, B.C., Canada from 1960 to 1993 measured by moss monitoring with Isothecium stoloniferum. Can. J. Bot. 74, 1345-1353.

Pott, U., Turpin, D.H. 1998. Assessment of atmospheric heavy metals by moss monitoring with Isothecium stoloniferum Brid. In the Fraser Valley, B.C., Canada. Water, Air, Soil Poll. 101, 25-44.

Salonen, V.P., Korkka-Niemi, K. 2007. Influence of parent sediments of the concentration of heavy metals in urban and suburban soils in Turku, Finland. Appl. Geochem. 22, 906-918.

Simonetti, A., Gariepy, C., Carignan, J. 2000. Pb and $\mathrm{Sr}$ isotopic compositions of snowpack from Quebec, Canada: Inferences on the sources and deposition budgets of atmospheric heavy metals. Geochim. Cosmochim. Ac. 64, 5-20.

Singh, S., Kumar, M. 2006. Heavy metal load of soil, water, and vegetables in peri-urban Delhi. Environ Monit Assess. 120, 79-91.

Snape, I., Scouller, R.C., Stark, S.C., Stark, J., Riddle, M.J., Gore, D.B. 2004. Characterisation of the dilute $\mathrm{HCl}$ extraction method for the identification of metal contamination in Antarctic 
marine sediments. Chemosphere. 57, 491-504.

Toronto Public Health. 2011. Assessing urban impacted soil for urban gardening: Decision support tool - technical report and rationale. Toronto, ON.
UBC Farm. 2009. Farm features. Retrieved on January 15, 2013, from http://ubcfarm.ubc.ca/.

Wiseman, L.S., Zereini, F., Puttmann, W. 2013. Trafficrelated trace element fate and uptake by plants cultivated in roadside soils in Toronto, Canada. Sci Total Environ. 442, 86-95. 